\title{
CORPORATE SOCIAL RESPONSIBILITY IN THE TIME OF FINANCIAL CRISIS: EVIDENCE FROM TURKEY
}

\author{
Yakup Selvi ${ }^{1}$ \\ Eva Wagner ${ }^{2}$ \\ Ahmet Türel ${ }^{3}$
}

\begin{abstract}
Corporate Social Responsibility (CSR) has been an important global issue all over the world. Proponents of CSR claim that it has lots of benefits for the company such as good reputation; on the other hand opponents claim that CSR can not protect a firm from financial harm in times of crisis. The objective of this paper is to conceptually examine the CSR, benefits of implementing CSR, and CSR activities in the time of financial crisis. In addition, a research was conducted to explore the impact of CSR on company reputation in Turkey by comparing the relationship between our CSR and reputation measures before and after the financial crisis. The evidence gathered shows that there is a positive and significant relationship between these two variables in both before financial crisis era and financial crisis era. However, the correlation between these two variables has not increased significantly between the two periods investigated.
\end{abstract}

Keywords: Corporate Social Responsibility (CSR), Reputation, Financial Crisis

JEL codes: $M 14$

\section{Introduction}

Corporate organizations that have become the most effective tool of realizing economic growth in this globalized world ought to be socially responsible to all members of the society. The idea of corporate social responsibility (CSR) is necessary for the goal of society's sustainable development. Due to the concerns over globalization of corporate activities, greater social awareness among consumers, more socially conscious workforce, and legislative changes, CSR is becoming an increasingly prominent global issue in all over the world. Since communities' attention is increasingly focused mostly on the "quality of life", which is the purpose of development, a corporate organization is expected to operate not simply for profit, but also in the interest of social harmony that is necessary for the realization of the good life for members of the society (Owolabi A. \& OluOwolabi E, 2009). The "quality of life" or "good life" is not only the satisfaction of the material needs but also the enhancement of the overall respect for the rights of all who are presently living members of the community and also for future generations. Therefore, the sustainable development, in the true sense of the concept, can only occur when all individuals and especially corporate organizations show respect, responsiveness, and responsibility to the entire society, in particular, and humanity, in general (Owolabi A. \& Olu-Owolabi E, 2009).

The remainder of this paper has been organized as follows. In section 2, the meaning of CSR is given. In section 3, the main benefits of implementing CSR are described. In section 4, CSR in the time of financial crisis is discussed. Section 5 presents the research, sample, and the results while section 6 concludes.

\footnotetext{
${ }^{1} \mathrm{PhD}$, Istanbul University, School of Business, email: selviyak@ istanbul.edu.tr

${ }^{2} \mathrm{PhD}$, Johannes Kepler University, Institute of Corporate Finance, email: eva.wagner_1@jku.at

${ }^{3} \mathrm{PhD}$, Istanbul University, School of Business, email: aturel@istanbul.edu.tr
} 


\section{The meaning of Corporate Social Responsibility}

Organizations should evaluate and analyze carefully the impact of their actions on the entire stakeholders, because we can define CSR basically as "a role of business in society as a social performance". CSR is about organizations taking account of the social and environmental impact of their decisions. CSR is defined as "a concept whereby companies decide voluntarily to contribute to a better society and a cleaner environment" by the Commission of the European Communities' (CEC) Green Paper on CSR. Although CSR is generally understood as a concept under which companies accept responsibility for social and economic needs, CSR is not confined to "good works", charity, social action or philanthropy. They may be part of CSR, but they are not to be identified with it (Argandoña A., 2009). CSR, therefore, includes fair treatment of the employees, transparent and honest relationship between the managers and the shareholders, careful consideration for the health, safety, and interests of the consumers. It also includes charitable contributions, promotion of the rights of the minorities and the vulnerable groups and, most importantly, serious consideration for environmental sustenance in order to ensure intergenerational equity (Owolabi A. \& Olu-Owolabi E, 2009).

Therefore, "a socially responsible organization has 'another' way of viewing problems, as it will always be aware of the consequences of its decisions on all of the people concerned: the managers themselves, employees, customers and suppliers, the local community, society as whole and even future generations (the environmental dimension)" (Argandoña A. ,2009). The idea of CSR is indeed an ethical issue because it originates out of the imperative that has become expedient in the modern world of corporations to be mindful of the interests and rights of the other (Owolabi A. \& Olu-Owolabi E, 2009). Only ethical responsibility may make a corporation enduring and lasting. Social performance is normally linked to ethical issues and includes: labour practices, human rights policy, product responsibility, and the enterprise's relationship with society. Therefore, in normative, CSR is concerned with what the organization must do, what is expected from it, and its obligations and duties, although these actions' compulsoriness is not founded on law but rather on some form of voluntary undertaking or ethical requirement (Argandoña A., 2009). On the other hand, organizations also have legal responsibilities which, insofar as they are also ethical responsibilities, will also be part of their CSR (Argandoña A., 2009). In actual fact, not everything is morally acceptable, therefore, CSR expects that business organizations should go beyond the laws and get to the realm of morality to be socially responsible (Owolabi A. \& Olu-Owolabi E, 2009). CSR refers to the need for organizations to show concern for the interest of their stockholders, their employees, their immediate host community, environment, and in fact, the entire humanity in general (Owolabi A. \& Olu-Owolabi E, 2009).

European Commission (EC) has issued a large number of directives relating to environmental and social issues, particularly in the area of pollution, emissions, waste and water, and is pursuing a major initiative on CSR. United Nations (UN) set up the "UN Global Compact in 2000", a voluntary initiative to enact standards for corporations maintaining human rights, labour, environment and anticorruption, with the mission of "an inclusive and sustainable global economy". Especially the UN Global Compact may encourage developments in the field of human rights? Since, the CSR movement began in 1971 there have been over 3600 businesses signing on to the UN Global Compact (Nicholas C., 2008-2009). Also, almost $80 \%$ of the largest 250 companies globally have issued CSR reports in 2008 where this figure was 50\% in 2005 (KPMG, 2008). The UN Global Compact has brought organizations to advance "ten universal principles" (see Table 1) in the areas of human rights, labour, environment and anti-corruption. 
Ten Universal Principles According to the UN Global Compact

\begin{tabular}{|c|c|}
\hline CATEGORY & PRINCIPLES \\
\hline $\begin{array}{l}\text { Human } \\
\text { Rights }\end{array}$ & $\begin{array}{l}\text { Business should; } \\
P-1: \text { support and respect the protection of internationally proclaimed } \\
\text { human rights; and } \\
P-2: \text { make sure that they are not complicit in human rights abuses. }\end{array}$ \\
\hline $\begin{array}{l}\text { Labour } \\
\text { Standards }\end{array}$ & $\begin{array}{l}\text { Business should uphold; } \\
P-3: \text { the freedom of association and the effective recognition of the right to } \\
\text { collective bargaining; } \\
P-4: \text { the elimination of all forms of forced and compulsory labour; } \\
P-5: \text { the effective abolition of child labour; and } \\
P-6: \text { the elimination of discrimination in employment and occupation. }\end{array}$ \\
\hline Environment & $\begin{array}{l}\text { Business should; } \\
P-7: \text { support a precautionary approach to environmental challenges; } \\
P-8: \text { undertake initiative to promote environmental responsibility; and } \\
P-9: \text { encourage the development and diffusion of environmentally friendly } \\
\text { technologies. }\end{array}$ \\
\hline $\begin{array}{l}\text { Anti- } \\
\text { corruption }\end{array}$ & $\begin{array}{l}\text { P-10: Business should work against corruption in all its forms, including } \\
\text { extortion and bribery. }\end{array}$ \\
\hline
\end{tabular}

The main benefits of implementing Corporate Social Responsibility

Being an essential part of business language and practice, CSR is in an exponentially growing path. Since CSR applications have a lot of benefits to organizations, they are increasingly assuming and integrating a social perspective in their culture. As a resume of key CSR benefits, the following can be highlighted (Fernàndez B. \& Souto F., 2009): responsibility.

a) Maybe, the most important benefit is the organizations satisfaction for its own

b) Getting a good reputation from community and getting better financial performance; linked to increasing market share, maintaining key personnel and directing investors' confidence towards CSR.

c) Assuming consumer selective elections that are increasingly including CSR criteria to make business more competitive.

d) Changing relationships all along the chain value, based on trust and doing things the right way with suppliers and customers.

e) Improving working climate, thus increasing employee permanence, motivation and productivity.

f) Reducing legal conflicts on complying with regulatory requirements.

g) Improving relations and implications within the local community, given the wide range of opportunities this question poses in terms of reputation, positive press and wealth.

h) Assuming positive and negative impacts of the company activity as a key question in management decisions, with a long-term perspective.

i) Re-designing processes with CSR green parameters, reducing waste that often simplifies operations and saves money.

j) Managing risks is, also, one of the main benefits of CSR in the short-term. To manage risks and to ensure legal compliance companies may be exposed to a variety of legal and reputational risks if they do not have adequate social compliance or CSR/Sustainability programs in place.

Although implementing CSR has above mentioned benefits, the world is still far away from the ideal situation of a global and unique framework for CSR. On the other hand, the implementation 
of responsible policies and strategies according to CSR plan is a long-term process and can always be improved. Therefore, the benefits of CSR application are widely recognized in the long-term and the cost of CSR implementation is also essential and cannot be forgotten (Fernàndez B. \& Souto F., 2009).

\section{CSR in the times of crisis}

The concept of CSR is much more widely accepted than ethics in the financial world after the current financial crisis. Generally crisis is a major occurrence with a potentially negative outcome affecting the organization, company, or industry, as well as its publics, products, services, or good name. The crisis raises doubts about the fate of CSR. As a strategic management tool, CSR helps companies prepare for the future and equips them to deal with crisis situations by providing a way for private industry to join together with policymakers and civil society to work for the common good all over the world (Peters A., 2009). In times of crisis, since organization's public relationships will be challenged, a good reputation for social responsibility may be a double effect (double-edged sword) (Dean D., 2004);

a) A sterling reputations benefits the company with goodwill;

b) But also, consumers will have high expectations for the company to act appropriately in a time of crisis to discharge its social responsibility.

Partly as a result of the combination of the economic and financial crisis with what has been called an entrepreneurial crisis of maturity, there is a growing realization of the need for CSR in the last decade. Since the financial crisis has not only economic causes but also psychological, social, political, and ethical causes in nature (Argandoña A., 2009) as well; there is a relationship between CSR and financial crisis. This relationship appears in following ways:

a) The lack of CSR is one of the causes of the current economic and financial crisis.

b) CSR is could be a tool for managing the crisis and helping firms to handle impacts of the crisis.

d) Using CSR is a business opportunity to be in a better position to overcome the turbulent situation of the current economic and financial crisis.

e) Long term benefits should be considered together with CSR's implementation costs.

In the times of crisis, there is a set of common issues between CSR and crisis. Following are the common issues between CSR and crisis (Fernàndez B. \& Souto F., 2009):

a) Innovation: CSR model implementation can be assessed as innovation, a key concept for achieving long-term entrepreneurial survival, a logical objective in situations of crisis.

b) Comfortable atmosphere: CSR provides the desired atmosphere (internal culture, motivation) in which exceptional periods (such as crisis) can be approached.

c) Stakeholders' role: CSR gives adequate treatment to stakeholders, changing their possible position of risk towards the firm to an attitude of alliance.

d) Business strategy: CSR implementation reinforces business strategy, a necessity always covered but which has special relevance in periods of crisis.

e) Market attitude: CSR model implementation strengthens companies' market position, when it is perceived as such. That is why communication and transparency are important. These two characteristics are inherent to CSR.

f) Investor confidence: CSR offers a guarantee and confidence to investors, due to information offered by responsible companies. Financial resources are always necessary but they become critical in times of crisis.

g) Deep internal reflection: CSR implementation obligates one to reflect deeply about main concerns clearly linked to long-range survival. 
On the other hand, there has been an ongoing discussion about "How would - or would not - CSR stand up to a deep crisis or recession" (Pinney C., 2009). Also, following questions are the main question marks related to CSR arises in the time of crisis.

a) Would it have been possible to avert the crisis if the various players had acted responsibly (in the meaning of CSR)? (Argandoña A., 2009). In other words, does CSR guarantee the success of a responsible organization, if it behaves responsibly?

b) Does a reputation for CSR protect a firm from financial harm in times of crisis?

c) Is the economic downturn affecting the willingness and readiness of organizations to look at the economic, social, and environmental impact of their business practices? Or, is this a perfect time to reassess current programs and adapt them to changing needs in society? (Lagace M.,2009).

d) Will even the most committed companies maintain their CSR programs, or will they be better off quietly cutting or dropping them to conserve cash? (Quelch J. \& Jocz K., 2009).

e) Since the world faces the worst financial crisis recently, who wants to hear about corporate social responsibility? (Heyzer N., 2008).

f) What is the responsibility of organizations when they operate in financial crisis economic conditions? And, how do organizations implement CSR policies in such conditions?

| There are some critics who may argue, that large international companies have little or no incentive to make changes in the way they operate their businesses. This scepticism can be attributed to the reality that most large international companies handsomely profit from the countries where labour cost is inexpensive. However, while profit does motivate these companies, stock prices can be tied to negative publicity. If a company has reputation to utilize a manufacturer with horrible labour conditions, then negative publicity could result in a decrease of its value (Nicholas C., 2008-2009).

Employing the strategy of reducing the offensiveness (such as to write messages that bolster, minimize, differentiate, transcend, attack the accuser, and offer compensation) has a more positive impact on publics' perceptions of CSR in times of crisis (Haigh M. \& Dardis F.). A sustainable reputation benefits the organization with goodwill, but it also means that consumers and society will have high expectations for the organization to act appropriately in a time of crisis to discharge its social responsibility. Reputation comes from the best practice of CSR is a driver in the crisis period. During the financial crisis, some of organizations have no major concern while the others take specific actions on CSR practices by reducing philanthropy / giving, increasing layoffs, and reducing R\&D for sustainable products (BCCCC, 2009). Therefore, one way organization can protect against the backlash of crisis or nurture the organization is public relationship through by practicing CSR activities (Haigh M. \& Dardis F.). In fact, regardless of crisis and recession, some organizations are capitalizing on the growing consumer interest in CSR to both "do good" and differentiate themselves at the same time (Quelch J.\& Jocz K., 2009). Organizations should begin crisis communication when there is no crisis, and if organizations do good works, publics may be more forgiving in times of crisis (Haigh M. \& Dardis F.).

In general, large organizations significantly increased their investments and involvement in CSR activities, but they were more likely to impose layoffs; small organizations stayed committed to their emphasis on treating employees well by minimizing layoffs during crisis (BCCCC, 2009). On the other hand, small organizations significantly decreased attention to other aspects of CSR activities while large organizations pay attention to important CSR principles right from the start.

In times of crisis, organizations focus on their costs firstly and try to minimize their costs. When organizations have to cut costs, the first casualties are always expenditures that seem to be not related directly to the core business. Therefore, the pressure for CSR cost cuts in the face of crisis or recession is often inescapable. In fact, some organizations are finding that pursuing environmental CSR initiatives during the crisis and recession is helping them to cut costs and increase their CSR budget without changing prices (Quelch J.\& Jocz K., 2009). The consequence is evident: CSR in periods of crisis is a threat for firms' survival and such a strategy is not expected in these times of 
uncertainty. The overuse of corporate sponsorship, based on CSR, only with marketing purposes, can change the customers' initial positive perception. Customer sensitivity is much more likely to break out in crisis periods. There are four progressive levels of CSR commitment (Quelch J.\& Jocz K., 2009) that affect the organization's act of CSR in the times of crisis:

a) First Level: There are companies that see CSR only in terms of corporate philanthropy. They find it relatively easy to cut their annual donations.

b) Second Level: There are companies that have integrated support for a social cause into their marketing programs to get reputation.

c) Third Level: There are companies who embedded their CSR considerations into their daily operations.

d) Fourth and last Level: There are companies that have internalized CSR values into their corporate cultures, mission statements and daily decision-making to maximize their stakeholders' interests via value creation to them.

CSR, by itself, probably does not guarantee the success, a high rate of sustainable growth, or a low unemployment rate, or grater macroeconomic stability of a responsible organization, if it behaves responsibly. On the other hand, it will be even more difficult to avert financial crisis without CSR implementation, since the financial crisis is averted also by the quality and efficiency of the regulatory and control mechanisms of an organization (Argandoña A., 2009). In the face of crisis, organizations that do not have a CSR strategy should start to develop it as soon as possible and those who have a CSR strategy should improve it at a level of well institutionalized, well communicated and well reported (Moller K., 2009).

Organization investments in social performance may provide intangible financial benefits namely reputation. A reputation for social responsibility provided the greatest benefit to firms facing the greatest crises. Although there is still a dearth of empirical support for the claim, some researchers suggest that firms with good reputations may better withstand crises with lesser economic losses than firms without good reputations (Schnietz K. \& Epstein M., 2005).

\section{The Relationship between Corporate Social Responsibility and Reputation in the Era of Financial Crisis in Turkey}

The relationship between CSR and the firm's reputation and consequently on economic performance is of great importance. Despite the extensive research on the so called CSP-CFP (Corporte Social Performance and Corporate Financial Performance) link (s. the meta analysis studies by Orlitzky M. et al., 2003, Margolis J.D. \& Walsh J.P., 2003 and Margolis J.D. et al., 2007), very little attention has been paid to the association between CSR and reputation. Reputation can be seen as the missing link: reputation is one of the most valuable asset of any firm (see Peloza, J., 2006) and could impact corporate financial performance respectively firm value. In this part of the study, the relationship between corporate reputation and social responsibility for a sample of Turkish companies is analyzed. In addition, the impact of CSR on company reputation in Turkey is explored by comparing the relationship before financial crisis during 2005-2006 with that of financial crisis during 2008-2009. Particularly, investigation is done to see whether there is a positive relation between CSR and company reputation and if so, whether the correlation between two variables has been changed during these two periods. Taking into consideration the benefits of CSR, the prediction is that there is a positive correlation between CSR and company reputation and also the correlation between these two variables increased during financial crisis. Therefore, it is possible to propose the following hypotheses:

1) $\mathrm{H}_{0}$ : There is no relationship between corporate social performance and reputation. $\mathrm{H}_{1}$ : There is a relationship between corporate social performance and reputation. 
2) $\mathrm{H}_{0}$ : The relationship between $C S R$ and reputation is equal in before financial crisis environment and financial crisis environment.

$\mathrm{H}_{1}$ : The relationship between $C S R$ and reputation differs in before financial crisis environment and financial crisis environment.

The sample selection process yields a before financial crisis environment sample of 26 firmyear observations and financial crisis environment sample of 25 firm-year observations according to the availability of reputation and CSR data. Therefore, this sample is not randomly selected. To measure corporate reputation, we utilize the "The Most Admired Companies in Turkey" survey from Capital (Ayvaci O., 2009). Table 2 presents the most admired companies of Turkey in the research period. The survey was conducted with the participation of 1,347 middle and high-level executives from 35 sectors. The participants were asked to evaluate on a scale of 1 to 10 the companies they liked according to 18 criteria such as innovation, provision of quality services, information and technology, customer satisfaction, investments in social responsibility, the importance given to employees.

To measure corporate social responsibility we utilize the "The Leaders in Social Responsibility in Turkey" survey from Capital (Oncel Bayiksel S., 2009). Table 3 presents the leaders in social responsibility in Turkey in the research period. The survey covers 1305 people, has been expanded to include the perceptions of business circles regarding corporate social responsibility in addition to those of the public. The participants were asked to evaluate the companies according to criteria such as environment, sport, social and cultural projects, human rights, etc.

The companies that take place in the "most admired" and "socially responsible" list for five year period (2005-2009) are matched with the rankings for the ones that take place in both of the lists. Next, the data list is split into two as before financial crisis era (2005-2006), and financial crisis era (2008-2009). We regard the year 2007 as a transition period from non-crisis environment to crisis environment and excluded from the study.

Table no. 2

The Most Admired Companies of Turkey

\begin{tabular}{|c|c|c|c|c|}
\hline & 2009 & 2008 & 2006 & 2005 \\
\hline 1 & Turkcell & Turkcell & Koc Holding & Turkcell \\
\hline 2 & Arcelık & Koc Holding & Turkcell & Arcelik \\
\hline 3 & $\begin{array}{l}\text { Garantı B./Koc } \\
\text { Holdıng }\end{array}$ & Arcelik & Arcelik & Koc Holdıng \\
\hline 4 & Coca Cola & Garantı Bankası & Sabancı Holdıng & Sabancı Holdıng \\
\hline 5 & Sabancı Holdıng & $\begin{array}{l}\text { Sabanc1 Holdıng/Coca } \\
\text { Cola }\end{array}$ & Vestel & Vestel \\
\hline 6 & Eczacibası Toplulugu & Eczacibası Toplulugu & Garantı Bankası & Garant1 Bankas1 \\
\hline 7 & Unılever & Unılever & Coca Cola & Ulker \\
\hline 8 & Ulker & Ulker & Unilever & $\begin{array}{l}\text { Coca } \\
\text { Cola/Unılever }\end{array}$ \\
\hline 9 & $\begin{array}{l}\text { T.Is Bankasi/Procter\& } \\
\text { Gamble }\end{array}$ & Doguş Holdıng & $\begin{array}{l}\text { Eczacibas1 } \\
\text { Toplulugu }\end{array}$ & $\begin{array}{l}\text { Eczacibası } \\
\text { Toplulugu }\end{array}$ \\
\hline 10 & Dogus Holdıng & Procter Gamble & Procter Gamble & Procter Gamble \\
\hline 11 & Turk Telekom & Vestel & Ulker & Zorlu Holding \\
\hline 12 & Vestel & Microsoft & Zorlu Holdıng & Dogus Holdıng \\
\hline 13 & Borusan Holdıng & Zorlu Holdıng & Doğuş Holdıng & Microsoft \\
\hline
\end{tabular}




\begin{tabular}{|l|l|l|l|l|}
\hline 14 & Microsoft & T Is Bank & Ford Otosan & T. Is. Bankas1 \\
\hline 15 & Toyota & Turk Telekom & Akbank & $\begin{array}{l}\text { Akbank/Ford } \\
\text { Otosan }\end{array}$ \\
\hline 16 & Siemens & Akbank & Anadolu Holding & Beko \\
\hline 17 & Bosch & P.Morris/Efes P1lsen & Microsoft & Boyner \\
\hline 18 & Efes P1lsen & Borusan Holdıng & Petrol Ofis1 & Efes \\
\hline 19 & Akbank & Bosch & T. Is. Bankas1 & Mav1 Jeans \\
\hline 20 & Tupras & Toyota/Siemens & Efes P1lsen/Bosch & Pfizer \\
\hline
\end{tabular}

Source: Ozlem Aydin Ayvaci, “En Begenilenler”, Capital, December 2009.

Since the data to be correlated are ordinal, the measurement is not based on an interval scale, we performed a correlation on the ranks using the Spearman $r_{s}$ correlation coefficient (Hinton, 2004). The test of correlation between CSR and company reputation supports the first prediction and shows that there is a positive and significant relationship between these two variables. However, the increase in correlation does not support the second prediction and shows that the correlation between these two variables has not increased significantly from the environment before financial crisis to the one of financial crisis. The correlation coefficient indicates the strength of the association between the CSR and company reputation. The correlation coefficient for each of the time period examined was $0,560(\mathrm{p}=0,002)$ in the before financial crisis environment, and $0,597(\mathrm{p}=0,003)$ in the | financial crisis environment. Both correlations are statistically significant at the $95 \%$ level.

Therefore, the first null hypothesis has been rejected and the conclusion can be defined as that there is a positive relationship between corporate social performance and reputation in Turkey. However, we fail to reject the second null hypothesis and conclude that financial crisis environment | does not bring greater reliance on CSR compared to non-crisis environment in Turkey.

Table no. 3

The Leaders in Social Responsibility in Turkey

\begin{tabular}{|c|c|c|c|c|}
\hline & 2009 & 2008 & 2006 & 2005 \\
\hline 1 & Sabanc1 Holging & Sabanc1 Holdıng & Sabanc1 Holdıng & Sabanc1 Holding \\
\hline 2 & Koc Holdıng & Koc Holdıng & Koc Holding & Koc Holding \\
\hline 3 & Turkcell & Turkcell & Turkcell & Turkcell \\
\hline 4 & Ulker & Ulker & Ulker & Arcelik \\
\hline 5 & Arcelik & Arcelik & Dogan Holdıng & \begin{tabular}{|l|} 
Eczacibas1 \\
Holding
\end{tabular} \\
\hline 6 & $\begin{array}{l}\text { Eczacibası } \\
\text { Holding }\end{array}$ & Eczacıbası Holdıng & Eczacibası Holdıng & Ulker \\
\hline 7 & Akbank & Akbank & Akbank & Sanko Holdıng \\
\hline 8 & Dogan Holding & Dogan Holding & Arcelik & Vestel \\
\hline 9 & Is Bankası & Zorlu Holding & Zorlu Holding & Beko \\
\hline 10 & Efes P1lsen & Avea & Danone & \begin{tabular}{|l} 
Efes P1lsen/Zorlu \\
Holding
\end{tabular} \\
\hline 11 & Grundig (Beko) & Coca-Cola & \begin{tabular}{|l} 
Dogus Holding \\
\end{tabular} & \begin{tabular}{|l} 
Dogan Holding \\
\end{tabular} \\
\hline 12 & Avea & Vestel & Efes P1lsen & Merinos \\
\hline 13 & $\begin{array}{l}\text { Anadolu Hay. } \\
\text { Emeklilik }\end{array}$ & Efes P1lsen & Is Bankası & Coca Cola \\
\hline 14 & Dogus Holdıng & Is Bankası & Vestel & Doguş Holdıng \\
\hline
\end{tabular}




\begin{tabular}{|c|c|c|c|c|}
\hline 15 & Hurriyet & $\begin{array}{l}\text { Anadolu Hay. } \\
\text { Emeklilık }\end{array}$ & Avea & Bosch/Avea \\
\hline 16 & Vestel & Grundig (Beko) & Coca-Cola & \multirow{5}{*}{ N/A } \\
\hline 17 & Zorlu Holdıng & Milliyet & Sanko Holdıng & \\
\hline 18 & Garanti Bankas & Aygaz & Milliyet & \\
\hline 19 & Coca-Cola & Sanko Holdıng & Garantı Bankas1 & \\
\hline 20 & Milliyet & Danona & $\begin{array}{l}\text { Anadolu Hay. } \\
\text { Emeklılık }\end{array}$ & \\
\hline
\end{tabular}

Source: Seyma Oncel Bayiksel, "Sorumluluk Yarisinin Yeni Oyunculari”, Capital, March 2009.

\section{Conclusion}

The time between 2008 and 2009 was the period of staying alive for companies. The struggle to stay alive forced many companies to return to vital necessities. Many projects and investments were postponed. However, there were still some companies that believed in the benefits of CSR and continued their CSR activities. CSR, by itself, probably cannot have averted the financial crisis and made it easier to come out of the recession, because many organizations do not practice it nor do they have the necessary culture to practice it, and a CSR culture cannot be improvised (Argandoña A., 2009).

Although the financial crisis looks like the morally good reason that organizations have been looking for to bend down the CSR actions, we believe that CSR is more important during a crisis or recession. Global CSR' principles can help organizations to make smart choices at the inception of the planning cycle and thus avoid contributing to conflicts that lead to crisis. Also, organizations will be in a better position to overcome the recession and turbulent situation of the current economic and financial crisis by using CSR as a business opportunity (Fernàndez B. \& Souto F., 2009).

For in globalized world, the long-term value and success of organizations are strongly linked to the integration of economic, social, environmental, and governance issues into corporate management and operations. Even though CSR is a new controversial concept, CSR is a fundamental strategy for achieving the sustainable development that our globalized world needs (Fernàndez B. \& Souto F., 2009). We believe that carefully planned and managed CSR efforts can be helpful in identifying ways to overcome this crisis and meet the social and ecological challenges of the sustainable future for organizations, governments and civil society at large.

We investigated the relationship of CSR and company reputation in Turkey and compared the association before and after financial crisis. The findings support our main prediction and show that there is a positive and significant relationship between the two variables in both before financial crisis era and financial crisis era. However, the results show that the correlation between the two variables has not changed significantly between the tested periods. The relationship between CSR and corporate reputation seems to be a robust one over time. As a conclusion, we can suggest that implementing CSR is one of the most important factors to get a good reputation from the community which could lead consequently to a better financial performance and an increase in firm value or market share.

\section{References}

1. Argandoña A., 2009, Can Corporate Social Responsibility Help Us Understand the Credit Crisis?, Working Paper WP-790, IESE Business School, University of Navarra, March.

2. Dean D.H., 2004. Consumer Reaction to Negative Publicity, Journal of Business Communication, 41 (2), pp.192-211. 
3. Fernàndez B., Souto F., 2009. Crisis and Corporate Social Responsibility: Threat or Opportunit?, International Journal of Economics Sciences and Applied Research, 2 (1), pp. 36-50.

4. Haigh M.M., Dardis F.E., 2008. Impact of Crisis on Corporate Social Responsibility and Organization-Public Relationships, Paper presented at annual meeting of the international communication association, TBA, Montreal, Quebec, Canada, http://www.allacademic.com/meta/p231871 index.html.

5. Heyzer N., 2008. Corporate Social Responsibility in the Midst of Financial Turmoil, speech of the Executive Secretary of the United Nations Economic and Social Commission for Asia and the Pasific at the 7th Asian Forum on Corporate Social Responsibility, November 20-21, 2008, Singapore, http://www.unescap.org/oes/statements/ST20081113-015-Corporate Social-Responsibility-in-the-Midst-of-Financial-Turmoil.pdf.

6. Hinton, P. R., 2004. Statistics Explained, 2. Edition, Routledge, p. 279

7. Kolawole A., Owolabi, Fadeke E. Olu-Owolabi, 2009. Corporate Social Responsibility and the Crisis of Development in Africa, Journal of Sustainable Development in Africa, Vol. 10, No. 4, pp. 218-232.

8. KPMG International, 2008. KPMG International Survey of Corporate Responsibility Reporting 2008, Geneva, October 2008.

9. Margolis, J. D., Walsh, J.P., 2003. Misery Loves Companies: Rethinking Social Initiatives by Business, Administrative Sciences Quarterly, 48, 268-305

10. Margolis, J.D., Elfenbein, H.A., Walsh, J.P., 2007. Does it pay to be good? A Meta-Analysis and redirektion of research on the relationship between corporte social and financial performance, Working Paper, July 26

11. Moller K., 2009. How the global financial crisis is strengthening Corporate Social Responsibility or 'Big Busines can be the good guys too', available online at http://www.oxfordleadership.com/CSR Article, July 2009.

12. Nicholas D. C., 2008-2009. China's Labor Enforcement Crisis: International Intervention and Corporate Social Responsibility, HeinOnline, The Scholar, Vol. 11:155, 2008-2009, pp.155194.

13. Orlitzky, M., Schmidt, F.L., Rynes, S.L., 2003. Corporate Social and Financial Performance: A Meta-analysis, in: Organization Studies, 24 (3), 403-441.

14. Ozlem Aydin Ayvaci, 2009. En Begenilenler, Capital, December 2009, 80-107.

15. Peloza, J., 2006. Corporate Social Responsibility as Reputation Insurance, Working Paper, University of Calgary, Haskayne School of Business, Alberta, Canada

16. Peters A., 2009. Pathways out of the crisis: CSR as a strategic tool for the future, Bertelsmann Stiftung, pp. 5.

17. Pinney C., 2009. Economic Crisis Demonstrates Corporate Citizenship and CSR are here to Stay, available online at http://3bl.me/rckmer, September 23.

18. Quelch J.A., Jocz K.E., 2009. Can Corporate Social Responsibility Survive Recession?, Leader and Leader, Summer 2009, Issue 53, pp. 37-43.

19. Schnietz K.E., Epstein M., 2005. Exploring the Financial Value of a Reputation for Corporate Social Responsibility During a Crisis", Corporate Reputation Review, Vol.7, No.4, pp. 327-345.

20. Seyma Oncel Bayiksel, 2009. Sorumluluk Yarisinin Yeni Oyunculari, Capital, March. 